\title{
The Theology of Julian's Hymn to King Helios
}

John Dillon

Julian's Hymm to King Helios has been described, reasonably enough ${ }^{1}$, as Julian's definitive attempt to crystallize the Roman religion. - that is to say, the Roman religion in the form in which Julian wished to revive it. It is plainly a work which was important to him, but it was also one which, if he is to be believed, was composed in remarkable haste. Let us dwell for a moment on the circumstances of its composition. Julian was in Antioch for the winter of $362 / 3$, preparing for his fatal campaign against Sapor the following summer. His relations with the citizens of Antioch, despite his best efforts, were bad. His attempts to relieve food shortages had heen illjudged, and had gone wrong, in the process alienating both the populace and the rich; his efforts to revive the local curia were unsuccessful; the debatcle concerning the temple of Apollo at Daphne had brought him into conflict with the Christians. By December about his only friend in the city was Libanius.

In the midst of all this, he composed a series of literary works, which reveal his state of mind: The Caesars, a satirical dialogue reviewing his predecessors in the principate, composed during the Saturnalia of Dec. 1517; Misopogon, the Beard-Hater, a bitterly ironic response to the lampoons that the Antiochenes were directing against him; Against the Galilaeans, a full-dress attack on the Christians, exhibiting much learning and effective use of both rhetorical and philosophical arguments; and the present work (composed, as he informs its dedicatee, his valued lieutenant Flavius Sallustius ${ }^{2}$, in honour of the festival of Sol Invictus on Dec, 25) which, as I have indicated above, constitutes an attempt to define the essence both of

1. Polymnia AmunssinD-Fowt)ev, Julian and Hellenism: An Intellectual Biography: Oxford 1981, P. $1+8$

2. Not identical with the author of the little Neoplatonic atechism. On the Gods and the IIorld (that was Saturninus Secundus Salutius), but a learned and sympathetic audience nonetlictess. 
his own religious belief, and of the revived, rationalized religious system that he wished to impose upon the Empire. It is very characteristic of Julian to take refuge from his practical problems in literary composition, and to transmute his indignation and disappointment into, not only satire and invective, but also ecstatic theologizing.

In the area of philosophy, Julian has no aspirations to originality. All he wishes to do, as he repeatedly assures us, is to set before us as faithfully as he can the divinely-inspired insights of his spiritual mentor, the Neoplatonist philosopher Iamblichus, At 146A, he refers to Iamblichus of Chalcis, who through his writings has initiated me not only into other philosophical doctrines but these also"; at 150D, he speaks again of amblichus, from whom I have taken this and all besides, a little from a great store; and finally, in his peroration (157B-D), he gives his friend Sallustius some indication as to the conditions under which he wrote this work ${ }^{3}$ :

"This discourse, my dear Sallustius, I composed in no more than

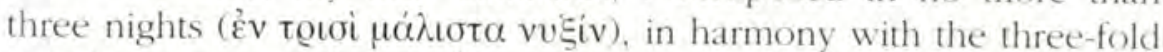
creative power of the god ${ }^{\prime}$, as far as possible just as it occurred to my memory; and I have ventured to write it down and to dedicate it to you because you thought my earlier work on the Kronia not wholly worthless. But if you wish to meet with a more complete and more mystical treatment of the same theme, then read the writings of the inspired Iamblichus on the subject, and you will find there the most consummate wisdom that man can achieve... For he is the source for what I have here set down, a few thoughts from many, as they occurred to my mind ".

This, on the face of it, seems to tell us pretty plainly the source of at least the main lines of Julian's doctrine in this work. We may now turn to a consideration of what we know of Iamblichus' theology, and see how well it is reflected by that of the Hymn to King Helios.

3. How literally this is to be taken is unclear, but it is certainly true that he woukd have had litte time to compose this work, and it does, despite a certain degree of organization. show signs of haste. Such prodigious speed of composition would perhaps be possible if in fact he was lifting the bulk of it from a work of Iamblichus, probably from his lost treatise On the Gods.

4. This is presumably a reference, not so much to the three worlds over which Helices presides (about which we shall learn more presently). but the three aspects of his power

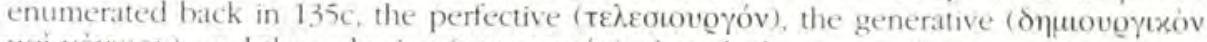
xat yovuov), and the cohesive (ouvextıxov), though there may also be a reference to the three levels of reality in which he exercises these influences.

5. BOWERSOCK is probably right to identify this with the Caesars (Julian the Apostate, Har vard I.P., Cambridge (Mass) 1978, p. 101 n. 21).

6. I borrow, for this and subsequent passages, the translation of W C. WRIGHT, in the Loet) edition, with slight alterations 
There are in fact considerable complications in the way of this. The problem is that Iamblichus, like many other later Neoplatonists, such as Proclus, Damascius, or the Alexandrian Hierocles, is prepared to present varying levels of complexity in his exposition of theological truths depending on the level of discourse, exoteric or esoteric, in which he is engaged. At his most elaborate, for instance in his lost Commentary on the Chaldaean Oracles or in his Commentary on the Timaeus. Iamblichus is prepared to envisage not only the three hypostases of Plotinian Neoplatonism, but a further absolutely ineffable first principle above the One, a dyad of entities, Limit and Unlimitedness, dependent on the One, and (very probably) a system of henads as well, while within the hypostasis of Intellect he (like Porphyry before him, indeed) distinguished a triad of "moments", or aspects, Being, Life and Intellect proper, or the intelligible", "intelligibleintellectual, and intellectual. levels, each of which in turn contain a corresponding triad of aspects. In fact, at his most elaborate, it would seem that he saw the lowest element in the realm of Nous as a hebdomad, presided over by the demiurgic Intellect ${ }^{9}$. And so on, down through Soul, Nature and the physical world, to Matter.

Few or none of these complexities will be apparent in the Hymn to King Helios (though in fact the last detail, about the demiurgic hebdomad, could be seen as having a certain relevance, as will emerge), and Iamblichus himself, in his more popular works, such as the Pythagorean Sequence, his De Anima, his Letters, or even the De Mysteriis, gives little hint of them, operating with a much simpler metaphysical scheme, which he also no doubt felt to be an adequate representation of the truth for the purpose at hand. In a theological passage of the De Mysteriis, for example (VIII 2-3) admittedly presented as an account of the system of the Egyptians, but in fact intended to accord with Platonic principles - we find a sequence of a supreme principle above intellect, followed by a demiurgic intellect; there is mention of other, inferior deities, but no mention of a world-soul. This is all very much simpler than Iamblichus at his most elaborate, but there is still a distinction between a supra-intellectual One and an Intellect. We will see presently how all this accords with what we find in the Hymn.

Before we turn to look at the text of the Hymn, however, there is one further aspect of Iamblichus' metaphysics that must be noted. On one topic lamblichus does seem to be at variance with both his predecessors and his successors, and that is the question of the existence of a distinct hypostasis of Soul. Of course, he recognises the existence of soul, at both the individ-

7 As we know from references in Damascius, De Principis, chs, 43, and 50-1

8. Fragments collected by me in Iamblichi Chalcidensis in Platonis Dialogos Commenta norum Fragmenta, Brill, Leiden 1973.

9. This emerges from Proclus report, at In Tim. I 308,18ff., of the system set out in an essay of Iamblichus entitled On the Speech of Zeus in the Timaeus, which Proclus makes use of to show up an inconsistency between it and lamblichus position in his Timaens Commentary ( In Tim. fr. 34 DitLoN), where he seems to identify the whole intelligible realm as demiurgic. 
ual and the cosmic levels, and even of a transcendent monad of soul c $\mathrm{cr}$. In Tim. fr. 50), but when it comes to apportioning a distinct level of being to Soul, we find an anomaly. In the identification of the subject matters of the various hypotheses of the second part of the Parmenides, where all other authorities identify Soul as the subject of the Third Hypothesis (i.e. $155 \mathrm{e} 3$ - $157 \mathrm{~b} 5)^{10}$, lamblichus, uniquely, declares it to concern the classes of being superior to us, angels, daemons, and heroes", and assigns no hypothesis to Soul as a whole, but takes the Fourth as concerning rational souls, and the Fifth as concerning whose secondary souls which are bound onto rational souls (that is to say, irrational souls) ${ }^{11}$

This is a remarkable development, which has something to do, I think, with lamblichus' assignment of a lower and more ambivalent status to soul in general. I would not bring this up now, however, were it not for the fact that it seems to explain a notable omission in the metaphysical scheme presented in the Hymn: that is, that no mention is made of a cosmic Soul assisting Helios in his work of administration of the world. The truth is, I think, that Helios, in his median manifestation, combines the functions of demiurge and transcendent soul. But this is to anticipate somewhat. Let us turn to the text ${ }^{12}$.

Julian begins his theological exposition as follows (132CD):

This divine and wholly beautiful universe, from the highest vault of heaven to the lowest limit of the earth, held together by the continuous providence of the god, has existed from all eternity ungenerated. is imperishable for all time to come, and is guarded immediately by nothing else than the Fifth Substance, whose culmination is the "beam of the sun" speak, by the intelligible world (vontós xóounos); but in a still loftier sense by the king of the whole universe, who is the centre of all things that exist " He, therefore, whether it is right to call him "that

10. Which, we may note, modern commentators prefer to regard rather as an appendix io the second Ilypothesis

11. Proct. In Parm. $1054,3+\mathrm{ff}=$ In Parm. fr. 2 Dulion.

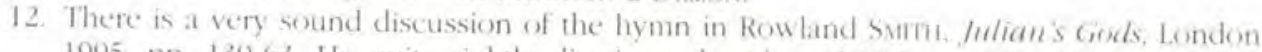
1995, PP. 139-63. He quite rightly dismisses the idea of Mithrac influence, but is not concerned with the details indulged in here.

13. Exric dexiov, a reference to Pindar's Paean 9 (Fr. $52 \mathrm{k}$ MAnuLk), or perhaps to Sophocles Amigone 100, where the phrase is also employed.

14. This refers, significantly, to a passage from the Platonic second letter (312e), now universally regarded as non-Platonic, but equally universally revered in later Platonist circles as Platonic, describing, in mysterious terms, a sequence of three principles: Jeoi

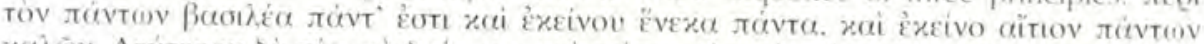

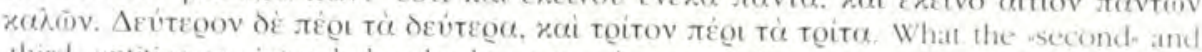
third entities are intended to be has never been satisfactorily explained, but the Nee, platonists saw them as referring to the hypostases of Intellect and soul, parallet to the second and third hypotheses of the Parmenides. 
which is beyond intellect" (

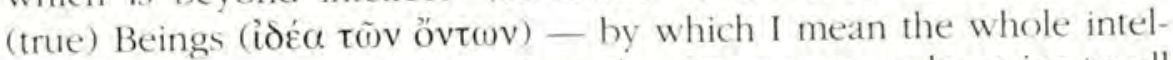
ligible realm - or the One, since the One seems to be prior to all the rest, or, to use Plato's term for him, the Good; at any rate this

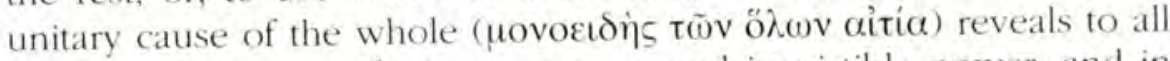
existence beauty, perfection, oneness, and irresistible power; and in virtue of the primal creative substance that abides in it, produced, as middle among the middle and intellectual creative causes, Helios the most mighty god, proceeding from itself and in all things like unto itself ".

Let us pause here and see what we have. In Neoplatonic terms, as I said above, it is a pretty simple scenario. It actually resembles rather more closely the metaphysical scheme of the Middle Platonist Numenius than the much more elaborate system of Iamblichus. Numenius, we may recall, is credited by Proclus with a triadic scheme of very much the type outlined

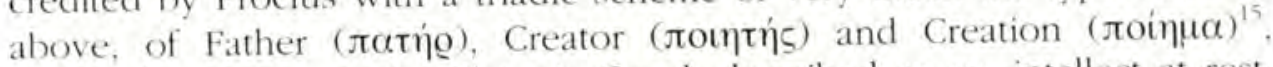
where the "Father" is the Platonic Good, described as an intellect at rest. (Fr. 15), as opposed to the Creator, or demiurgic intellect, which is in motion - albeit intellectual motion. This secondary divine intellect concerns himself about Matter, and generates the physical cosmos, which is thus styled, on the one hand, a god, but on the other, a work of creation $(\pi \circ i \eta \mu \alpha)$. Once again, the World-Soul does not appear as such, though Numenius certainly believed in such a soul; it is subordinated, however, to the Demiurge, and not accorded a hypostatic status of its own.

An even closer resemblance, however, is exhibited by a number of fragments of the Chaldaean Oracles. In Fr. 73, quoted by the later Neoplatonist Damascius ${ }^{16}$ (who is concerned to link it with a sequence of three "Zeuses", viz. Zeus himself, Poseidon, and Hades/Plouton, but we need not follow him in that), we find a most interesting triadic sequence of entities, the lowest of which, at least, seems to have the role of heating the earth, and may thus be identified with the physical sun:

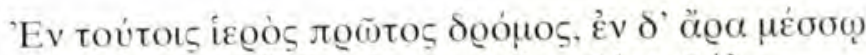

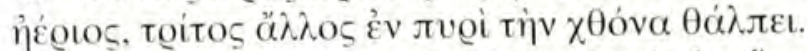

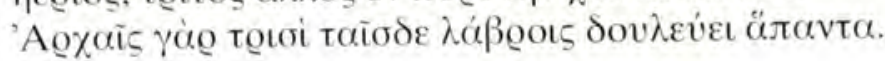

Among them ${ }^{17}$ the first course is sacred, while in the middle the course is aery, and there is another, third one which warms the earth

15. In Tim. I $303.27 \mathrm{ff}=\mathrm{fr} .21$ DES PLACEs. This is broadly confirmed by the various verba tim extracts from his dialogue On the Good preserved by Eusebius.

16. De Princ. IIn Parm./II 217,7 ff. Rufue.

17. Damascius wishes this to refer to a set of three Fathers, whom he is identifying, as I have said, with three Zeuses, the heavenly, the median, and the chthonian. It is more likely. however. that the original reference was to a set of three -world-rulers. 
with fire. For to these three turbulent ruling principles all things are in thrall.

The sense of this is admittedly less than perspicuous in all its details, but it is at least clear that we have a sequence of three dromoi, the last of which warms the earth with fire. One could be forgiven, I think, for assuming that we have here a sequence of three "suns", the highest of which is purely intelligible, while the median one, though associated with aêr, is yet supraphysical.

In fact, we know ${ }^{18}$ that the system of the Chaldaean Oracles distinguished three kosmoi, or levels of reality, the empyrean ( $\dot{\varepsilon} \mu \pi v \dot{Q} \varrho \varsigma$ ), which is tran-

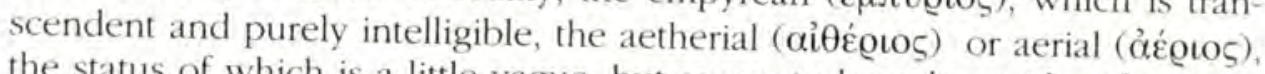
the status of which is a little vague, but seems to have been identified with the outer rim of the heavens, or circuit of the fixed stars, and the chthonian

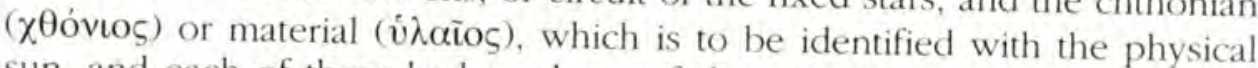
sun, and each of these had a ruler or "father. From an important passage of Proclus' Platonic Theology (IV 39, pp. 111-2 S-W), we can see that each of these rulers performs sun-like functions with respect to his level of reality, and this would make it relatively easy for Julian, or some mentor of his (perhaps Iamblichus, in his commentary on the Oracles; or perhaps just Julian's guru, Maximus of Ephesus), to graft onto such a scheme a refinement of Mithraic doctrine, which would postulate a triadic sequence of Supreme God - Mithras - Sun in place of the basic Mithraic doctrine, which involved only Mithras himself, identified with the sun, as mediator between the human and divine realm, and the supreme deity, Ahura Mazda. Admittedly, we have, in western Mithraism, numerous representations of Helios, the sun-god, subordinating himself to Mithras (the so-called investiture scenesn), and there are also numerous inscriptions where Mithras is described as Sol Invichus ${ }^{19}$, but we lack evidence of a clear triadic system.

On the other hand, in that curious document preserved among the Greek Magical Papyri, the so-called "Mithras Liturgy" (PGM IV 475-829)" we find clearer evidence of a triadic system and the adoption of theurgic practices, which brings us closer to the system of the Oracles $^{21}$. In the Liturgy, which is a description of a magician's ascent, with the help of theurgical practices,

(zoofucyoi), each presiding over a distinct level of reality, or -world. There are various references to a sequence of worlds in the Oracles (e.g. frs. $8,27,37,51$ ). The whole topic is well set out by Hans Lewy in Chaldaean Oracles and Theurny. Cairo 1956. Pp.
$137-57$.

18. E.g. from Proclus, In Tim. II 57.9 ff, and Psellus, Hypot 3 (p. 198 DFs PLACES).

19. See on this David Llansey, The Origins of the Mitbraic Mysteries, Oxford 1989, ch. 7 , who gives it good account of the evidence, with reference to previous discussions by
Roger Beck and Richard Gordon.

20. Translated, with notes, in H.D. BËz (ed.), The Greek Magical Papyri, Chicago 1980

21. For this connexion, I am indebted to the excellent paper of Radeliffe Enmoniss delive red at the panel on Theurgy at the Chicago meeting of the American Philological Association in Dec. 1997 (soon, I hope, to be published), entitled -Did the Mithraists Inha-
le. 
into the celestial regions, the first realm is the earthly region, from which he departs at the beginning of the rite; the second is the realm of the astral deities, through which the magician passes to reach the "fiery doors" ( $\pi \dot{\varrho} \varrho ı \alpha_{\imath} \theta \dot{v} \varrho \alpha$ ), beyond which is the realm of the gods. This the magician does not enter, but gods descend to him from this, including MithrasHelios himself (634ff.). Franz Cumont ${ }^{22}$ was inclined to deny that this document had anything to do with Mithraism, but more modern authorities, such as Beck ${ }^{23}$ have shown that there are sufficient connexions to allow it to be characterized at least as a product of late antique syncretism, rooted in traditional Mithraism. At any rate, we have substantial testimony to the existence of a triadic succession of worlds operative in the "Platonic underworld" of the second century A.D.

It is this sort of triadic scheme that seems to find its way into the Second Platonic Letter (312E), possibly itself a product of the same period ${ }^{24}$, which presents us with an intentionally mystifying formulation, as follows:

"The matter stands thus: related to the King of All are all things, and for his sake they are, and of all things fair he is the cause. And related to the second are the second things; and related to the third the third. About these, then, the human soul strives to learn, looking to the things that are akin to itself, whereof none is sufficient to the task. But as to the King and the objects I have mentioned, they are of quite different quality.

This text, as noted above (n.13), was plainly in Julian's mind when composing the passage above-quoted, and must be added to the sources on which he drew.

What we seem to have, then, in Julian's Hymn to Helios is essentially a triadic scheme of this sort, with the physical sun identified as the active principle of the cosmos, and so being presented as the third god, the second, median realm occupied by Mithras-Helios, and the highest by a supreme deity. The only aspect here distinctive of Iamblichean metaphysics would seem to be the characterisation of the realm of Helios himself, qua secondary god, as noeros, "intellectual", as opposed to noêtos, "intelligible", or "object of intellection", which is reserved for the first god. This first god is

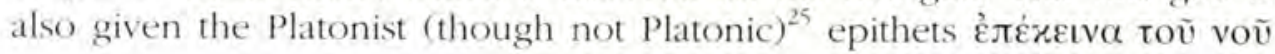

22. Textes é monuments figurés relatifs aux mystènes de Mithra, 2 vols., Brussels 1896-9, II P. 56

23. E.g. -Interpreting the Ponza Zodiac II, Journal of Mitbraic Studies, 2, 1978, p. 12.

23. If we are prepared to entertain the proposal of Harold TARRANT, Thrasyllan Platonism. Cornell 1993. Pp. 170-3, that it is a creation of Thrasyllus. It is certainly post-Platonic

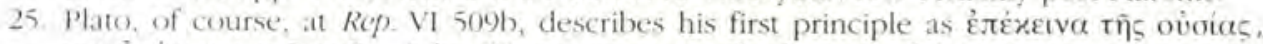

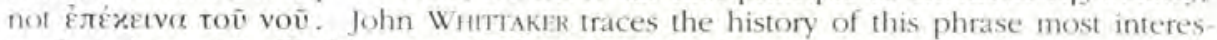
tingly in his article "Eréxetva voû xai oủoias". Vigiliae Christianae 23, 1969, pp. 91-10, (repr. in Studies in Platonism and Patristic Thought. Aldershot 1984). As for idéa tồv 


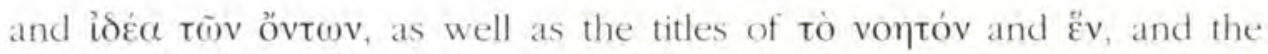
epithet ó $\pi \dot{\alpha} \tau \omega \mathrm{v} \beta \alpha \sigma t \lambda \varepsilon \dot{s}$, derived from the Second Letter. This all fits well enough with the metaphysical scheme presented by lamblichus in De Myst. VIII, as I have pointed out earlier, but not with his more esoteric system. On the other hand, this scheme is all that Julian requires to make his point on this occasion.

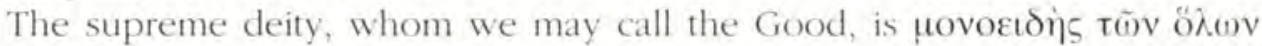
airia ${ }^{26}$. which conveys to all creation meauty, perfection, unity and infinite power - or, as it is rephrased just below, beauty, existence, perfection and unity. (133B) — and primarily to its immediate offspring, the mediating and demiurgic divinity which Julian here identifies with Helios proper.

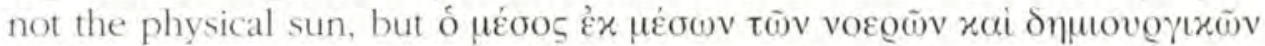

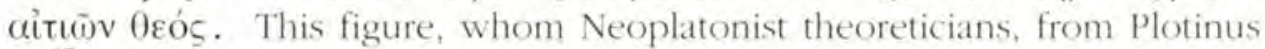
$\mathrm{on}^{27}$, identify with Zeus (as will Julian himself a little later on, at $143 \mathrm{D}$ and $144 \mathrm{~B})$, is now, interestingly, credited with the description which in the Republic (V1 508B) Plato accords to the visible sun: "offspring of the Good, which the Good begat in his own likeness", and so on. However, he is not the visible sun; instead, he dispenses to the intellectual gods those things of which the Good is the cause for the intelligible gods.

This introduces a complication. Who are these classes of gods? In the case of the intellectual gods about Helios, they would seem to be the transcendent archetypes of the planetary gods, such as Ares and Aphrodite, together with traditional Olympians such as Athena who are not identified with planets, and other not-so-traditional divinities, such as Sarapis - although it emerges later that he, together with Zeus, Apollo, Dionysus and Mithras, is rather to be identified with King Helios than to be a member of his train (cfr. 136A). What, on the other hand, are we to make of the intelligible gods presided over by the Good itself? Here, I think, we have evidence of a feature of Iamblichean metaphysics in which I have taken some interest in the past, though without adducing the present work ${ }^{2 \pi}$, and that is his postulation of a class of entities which were to take on considerable importance in the doctrine of the later Athenian school of Syrianus and Proclus, the so-called henads.

In Proclus, these are archetypes, in the realm of the One, of the Forms which are the contents of the realm of Intellect, and are a very curious class of entity indeed, since their existence is not meant to compromise the essential unitariness of the henadic realm, but yet they serve as bridges, of

övtov, Plato uses the phrase $\eta$ toṽ ôvtos idéa at Rep. VJ $486 d$, hut with a quite different meaning, nowhere does he use this term to characterize his first principle

26. A no douht lamblichean expression, but one which tums up otherwise only later, $* g$.

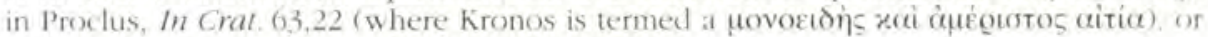

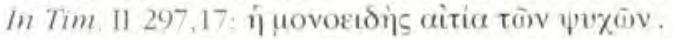

27. F.g. Enn. III 5,8; IV 4.10; V 53,21

28. - Tamblichus and the Origin of the Doctrine of Henads, Phronesis 17, 1972, pp, 102-6, (repr in The Ciolden Chain. Aldershot 1991); -Iamblichus and Henads Again-, in The Divine lamblebus, edd. H. Blumenthal - E.G. Clark, Bristol 1993, pp. 48-54. 
a sort, to the multiplicity of the realm of Nous. I had argued for their presence already in Iamblichus philosophy, and this proposal was countered by such formidable authorities as Leendert Westerink and H-D. Saffrey (in Vol. III of their Budé edition of Proclus Platonic Theology), whereat I did not withdraw my proposal, but modified it to accord with what I take to be Iamblichus' somewhat less complex metaphysical scheme. Here, it seems to me, we have a glimpse of these entities, firmly established in the realm of the Good. They appear more clearly still in a later passage (138D-139A) to which we may now turn, since in it Julian gives a clearer exposition of what he means by the uroótrs of King Helios.

It does not, of course, consist, as he says, in the mere fact of being equally remote from two extremes, but rather in heing that which unifies and links

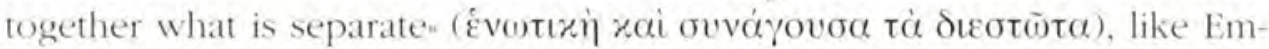
pedocles hamonia. So then, asks Julian, what is it that Helios links together, and of what is he proos?

"I assert, then, that he is midway between the visible gods within the universe and the immaterial and intelligible gods which surround the Good - the intelligible and divine substance being as it were multiplied without being acted on externally and without addition

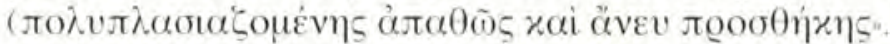

He expands on this a little further on (139BC):

The intelligible realm is completely one, pre-existent always, and it combines all things together in the One. Again, is not our whole world also one complete living organism, wholly throughout the whole of it full of soul and intelligence, "perfect product of perfect parts" ? Midway, then, between these two types of unitary perfection - I mean that one kind of unity holds together in one all that exists in the intelligible world, while the other kind of unity unites in the visible world all things into one and the same perfect nature - between these, I say, is the uniform perfection of King Helios, established among the intellectual gods".

The most curious thing about Julian's exposition here, from the perspective of later Neoplatonism, and one would have thought also from that of Iamblichus, is the way in which, in his description of his supreme principle, he combines features characteristic of the realm of Nous with those of the One. He talks of the highest level of existence as being voptov, an object of intellection, and as having its contents $\pi \dot{\alpha} v \tau \alpha$ ó ov , all together - a characterization of the intelligible realm which Plotinus borrows from Anaxagoras, and which he employs repeatedly ${ }^{30}$ - while yet making clear

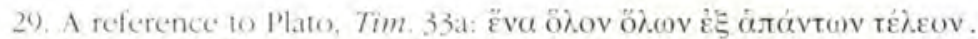

30) I, I I $1,8,8$; III $0,6,23$; IV 2,2,44; IV $7,11,27$. 
that it is also One and abeyond Intellect" and the Good. It is notable, certainly, that lamblichus too seems to have referred to his highest realm or at least the lowest aspect of that realm, the "One-Being", wherein his henads properly reside - as vontó $v^{31}$, as being the immediate object of Intellect's contemplation, but it is nonetheless true that in his more technical works he makes a strong distinction between the realms of the One and of Intellect, which Julian is not doing here. On the other hand, in the theology of De Myst. VIII 2-3 no such clear distinction is made, but only the sort of distinction which Julian is making. If, then, the theology of the Hymn is Iamblichean, it reflects Iamblichus in his "popularizing", exoteric mode.

However, I think by now that I have presented enough evidence both to make clear the basic structure of Julian's metaphysical scheme, and to show that it is by no means as complex as one would expect from a selfconfessed devotee of Iamblichus. The solution to the problem is, I believe, that Julian is concerned to present a system - essentially Chaldaean, with some Neoplatonic overlay - which is simple enough to highlight the central role which he wishes to assign to Helios in the scheme of things, and what he is borrowing from Iamblichus - specifically from his treatise $O n$ the Gods (which may in fact, for all we know, have presented a relatively simplified metaphysics, if it was of a popularizing nature) - is rather the details of his equivalences between various gods, Hellenic and other, as well as Iamblichus' characteristic mode of exposition, which we can observe also in his treatise On the Soul, of discussing first the essence

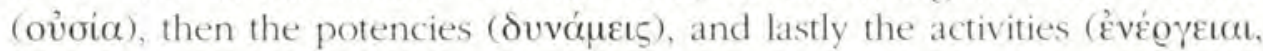
$\varepsilon$ e $\gamma \alpha$ ) of the entity under discussion. Julian announces this scheme at $132 \mathrm{~B}$, and duly carries it out, speaking of the ousia of Helios up to $142 \mathrm{~B}$, when he turns to an account of his dynameis, and then at $144 \mathrm{D}$ to his erga, first the hypercosmic, then the celestial, and lastly those operative in the sublunary sphere (150Dff.).

In this connexion, let me draw attention to a bit of Neoplatonic scholasticism which Julian is almost certainly deriving from Iamblichus, though it cannot be matched from Iamblichus' surviving works. Back in 135C. he isolated three chief functions of Helios, which have been bestowed upon him by the First Principle, his perfective power ( $\tau \varepsilon \lambda . \varepsilon \sigma ı v o \gamma o v$ ), his creative

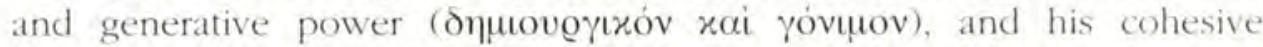
power (ouvextıxóv), by which he draws all things together into one whole. These are mentioned again at 151B:

"I said then (sc. 135C) that Helios holds sway among the intellectual

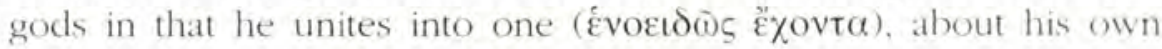


undivided substance, a great multitude of the gods; and further, I demonstrated that among the gods whom we can perceive, who revolve eternally in their most blessed path, he is leader and lord; since he bestows on their nature its generative power ( fills the whole heavens not only with the visible rays of light but with countless other blessings that are invisible; and further that the blessings which are supplied by the other visible gods are made

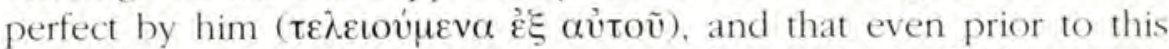
the visible gods themselves are made perfect by his ineffable and divine activity".

This summarizes very satisfactorily the role that Julian has chosen for the Sun-God, a deity to whom his devotion was very real. There is heartfelt testimony to this at the beginning of the hymn $(130 \mathrm{C})$ :

For 1 am a follower (óradós) of King Helios. And of this fact 1 possess within me, known to myself alone, proofs more certain than I can give ${ }^{32}$. But this at least I am permitted to say without sacrilege, that from my childhood an extraordinary longing for the rays of the god penetrated deep into my soul; and from my earliest years my mind was so completely swayed by the light that illumines the heavens that not only did I desire to gaze intently at the sun, but whenever I walked abroad at night, when the sky was clear and cloudless, I abandoned all else without exception and gave myself up to the beauties of the heavens; nor did I understand what anyone might say to me, nor heed what I was doing myself".

This gives us a vivid impression of the state of mind of a nervous and impressionable adolescent cooped up, as he then was, in the fortress of Macellum, wating to learn what his fate at the hands of his cousin Constantius was to be. There can be no doubt that reverence for the Sun was an important aspect of his personal religion. This receives confirmation from, among other sources, the remarkable autobiographical myth, or parable, that he tells to the Cynic Heraclius in the course of his response to him $(228 \mathrm{C}-234 \mathrm{C})$. There he presents Helios as addressing him as his own son and chosen representative on earth, in circumstances that reveal also his very ambivalent attitude to the role of imperial ruler that he has had to take on.

Another offspring of Helios, however, who is given a brief mention in the Hymn, does seem to have formed an important part of Julian's projected religious revival, and that is the saviour god Asclepios. Asclepios receives only two mentions in the Hymn, at $144 \mathrm{~B}$ and $153 \mathrm{~B}$, but these make it plain

32. A reference to his initiation as a Mithraist, which may have taken place as early as 351 A.D. By this time Julian had presumably ascended through all the grades of the cult, up to the rank of Father (pater). 
that Julian intends him as a sort of sanitized and rationalized version of Jesus Christ. At $1+4 \mathrm{~B}$ he says of Helios: and since he fills the whole of our life with fair order, he begat Asclepios in the world, though even before the beginning of the world he had had him by his side" - with a shrewd dig at, in particular, the Johannine description of Christ; while at $153 \mathrm{~B}$ we find the following: "Shall I now go on to tell you how Helios took thought for the health and safety of all men by begetting Asclepios to be the saviour of the whole world?. This propensity to boost Asclepios as saviour is much more pronounced, not unnaturally, in his treatise Against the Galilaeans, and was plainly a major preoccupation of his in this period.

But we are straying from philosophy in the strict sense rather into the realm of propagandistic theology. To return to philosophy, there is just one further detail to which I would like to draw attention, and that is Julian's assertion of the incorporeality of light. This is a doctrine, ultimately based on a creative misinterpretation of what Aristotle is saying about light in De Anima II 7, 418 b3ff,, that commended itself to Plotinus, and to all later Neoplatonists, Julian makes use of it at 133Dff. to define the peculiar anagogic power of the sun's rays:

"But this visible disc also, third in rank, is clearly, for the objects of sense-perception the cause of preservation, and this visible Helios is the cause for the visible gods of just as many blessings as we said the mighty Helios bestows on the intellectual gods. And of this there are clear proofs for one who studies the unseen world in the light of things seen. For in the first place, is not light itself a sort of incorporeal and divine form of the transparent in a state of activity? And as for the transparent itself, whatever it is, since it is the underlying basis, so to speak. of all the elements, and is a form peculiarly belonging to them, it is not like the corporeal or compounded, nor does it admit qualities peculiar to corporeal substance.... And of light, itself incorporeal, the culmination and flower, so to speak, is the sun's rays. Now the doctrine of the Phoenicians, who were wise and learned in sacred lore, declared that the rays of light everywhere diffused are the undefiled incarnation of pure mind ${ }^{34}$. And in harmony with this is our theory, seeing that light itself is incorporeal, if one should regard its fountainhead, not as corporeal, but as the undefiled activity of mind pouring light into own abode; and this is assigned to the middle of the whole heaven, whence it sheds its rays and fills the heavenly spheres with vigour of every kind and illuminates all things with light divine and undefiled.

33. What he is referring to here 1 cannot be sure Certainly, for the Chaldaean oractes

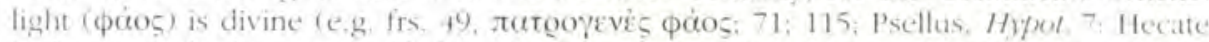
is the particular bestower of light). But this seems slightly odd way for Julian to - fefer to them, 
This doctrine enables Julian to present the sun's rays as the perfect conduit linking the immaterial with the material realm, but it constitutes an interesting instance of the overlaying of Aristotelian doctrine (albeit miunderstood) with Mithraic and theurgic (Chaldaean) influences to produce something thoroughly characteristic of Julian himself. He is not a great philosopher; nor would he claim to be. But he is no fool either, and it is a matter of considerable fascination to see how he makes use of the Neoplatonism of his time for his own practical, if rather quixotic, purposes ${ }^{3 t}$.

34. This paper was initially presented to a seminar on the Emperor Julian at Cambridge in November 1997, and it profited greatly from discussion at that forum. The paper of Radeliffe EDmovis (mentioned above, n. 21), also helped greatly to clarify my mind on the essentially Chaldaean origin of Julian's metaphysical scheme here. 